\section{French research minister waters down CNRS reform}

Paris

French science minister Claude Allègre has asked the directors of France's main research agency, the Centre National de la Recherche Scientifique (CNRS), to come up with more moderate changes to the agency's structure than those initially proposed by the government last year.

In a letter to CNRS president Edouard Brézin and director-general Catherine Bréchignac, Allègre asks them to focus on recruiting young scientists and increasing the mobility of researchers. The minister also says the reforms should concentrate on developing new disciplines, reducing administrative loads, and moving towards the "europeanization" of large-scale facilities and scientific evaluation.

To attain these objectives, Allègre writes: "I ask you to concentrate on some essential aspects that permit a deep modernization, without revolutionizing the organism". Earlier, more radical proposals were withdrawn after protests from the scientific community (see Nature 397, 463; 1999). Following disputes between research unions and the research ministry, prime minister Lionel Jospin appointed a parliamentary commission to study research reforms.

The commission spent three months consulting French scientists, and reported its proposals to the minister in July. But although much was said about the need to reform the CNRS, no action has been taken within the organization itself.

"This is only the prolongation of a process that has been going on for some time," says Brézin of the new reform proposals. But he is optimistic that it is a step in the right direction. "The project one year ago came as unexpected from the minister and myself, and that was a mistake. This time, I think we have taken a different approach. Now we are instructed to negotiate with the boards and the unions."

The scientific community may be soothed by Allègre's wish to preserve the National Committee for Scientific Research. His desire to slim down the committee was one of the more controversial aspects of last year's proposals. The committee acts as the 'parliament' of the country's scientists, and is involved in evaluating laboratories and administering recruitment.

Brézin says that one of the most urgent needs is to open up the seven scientific departments of the CNRS to allow disciplines to interact. Heather McCabe

\title{
'Relevant' teaching turns UK children back on to physics
}

\section{London}

Twenty-five British schools are piloting a new approach to teaching physics to $16-$ to 19 -year-olds that is already said to be attracting those who might otherwise have deserted the subject.

'Advancing Physics' is intended to bring "physics teaching firmly into the twenty-first century, using relevant and up-to-date examples of physics from everyday life". It is part of a $\mathfrak{E} 1$ million (US\$1.6 million) initiative by the UK Institute of Physics (IoP) to be launched at next month's annual meeting of the Association for Science Education.

Supported by the Institute of Electrical Engineers and the Particle Physics and Astronomy Research Council, the course uses a range of teaching approaches, examples of applications, and work for students. There is also a CD-ROM with activities that use the computer for doing physics.

The IoP say that schools involved in pilot studies have reported increased enthusiasm for physics among students, and that in one school physics became the most popular choice for sixth-form study. One aspect of the course is the way it uses the manipulation of images to bring together the aspects of what has become a disparate subject.

Mick Brown, a physicist at the Cavendish Laboratory at the University of Cambridge who has been assessing the course for the IoP, describes this feature as "wonderful". "It puts acquisition, manipulation and display of information at the centre of physics, and in doing so unites astronomy, cosmology, highenergy physics and applied physics," he says.

John Ogborn, professor of science education at the University of Sussex, who has been

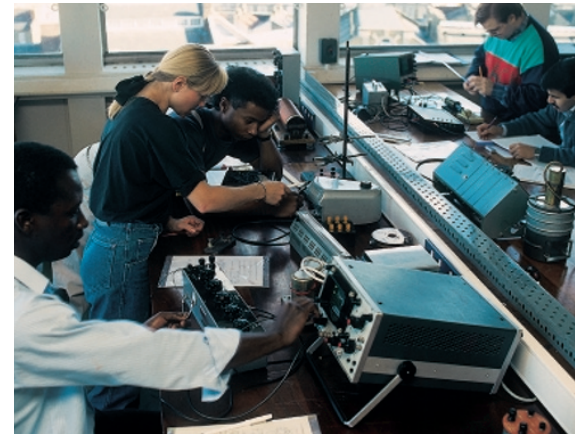

Turn off? Critics argue that traditional ways of teaching physics need a thorough review.

involved in designing the course, says that the IoP is concerned at the falling numbers of young people going into physics. To make the subject more attractive, Ogborn's group has created what he describes as a package with a core of essential work and an engineering flavour, relating to skills useful in jobs.

But the course's design was constrained by the fact that 60 per cent of the subject content is prescribed by a central authority the Qualification and Curriculum Authority - which approves A-level courses. Advancing Physics is in the last stages of obtaining official approval.

The core curriculum is intended to let universities know what to expect from students. Ogborn say that those who developed the new course had to be "inventive". The way that sensors work, for example, was used to teach how direct currents operate.

Brown points out that attracting more students to physics will be "a long process that will involve enthusiastic teachers, students and backup on the web". Natasha Loder

\section{Lots more cash for UK universities}

\section{London}

The UK government and the Wellcome Trust have announced the biggest investment in the infrastructure of university sci-

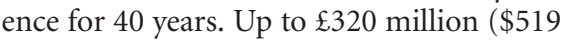
million) will go to 45 projects in 27 universities, as part of a second round of awards intended to compensate for years of underfunding (see Nature 399, 187; 1999).

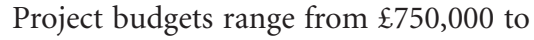
$£ 30$ million, although exact amounts will depend on the outcome of a procurement review. Overall, the University of Cambridge looks set to do best from this round of Joint Infrastructure Fund (JIF) awards, with bids

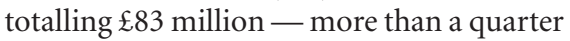
of the round's fund.
But the largest bid - for more than $\mathfrak{E} 30$ million - is for a new chemistry research laboratory at the University of Oxford. Successful bids include the refurbishment of the Lovell Radio Telescope at Jodrell Bank ( $\mathfrak{2} 2.3$ million) and a facility for research into dark matter ( $£ 3.8$ million) at the University of Sheffield.

Michael Dexter, director of the Wellcome Trust, says that many high-quality bids had to be turned down. An award fund of $£ 750$ million has received bids for more than $\mathfrak{E} 2$ billion. The scheme was set up in July 1998, and is funded by $£ 300$ million each from the government and the Wellcome Trust, and $\mathfrak{E} 150$ million from the Higher Education Funding Council for England. 